\title{
KEPERCAYAAN DAN SIKAP KONSUMEN TERHADAP MINAT PEMESANAN HOTEL DI TRAVELOKA
}

\author{
Amelia Helen Minarto ${ }^{1}$, Eugenia Felita ${ }^{2}$, Sienny Thio ${ }^{3 *}$ \\ 1,2,3 Program Manajemen Perhotelan, Program Studi Manajemen, Fakultas Bisnis dan Ekonomi \\ Universitas Kristen Petra, Jl. Siwalankerto 121-131, Surabaya \\ Email: ${ }^{1}$ ameliahelen03@gmail.com; ${ }^{2}$ eugenia.felita@gmail.com; ${ }^{3}$ sienny@petra.ac.id \\ *Penulis korespondensi
}

\begin{abstract}
Abstrak
Penelitian ini bertujuan untuk mengetahui pengaruh kepercayaan yang dilihat dari utility, trust, dan quality terhadap sikap dan minat melakukan pemesanan hotel di Traveloka. Penelitian ini menggunakan pendekatan kuantitatif dengan menyebarkan kuesioner kepada 110 responden yang pernah melakukan pemesanan apapun pada Traveloka dan membaca ulasan online mengenai hotel di Traveloka dalam 2 tahun terakhir. Pengolahan data menggunakan Analisa multivariat dengan menggunakan teknik Structural Equation Modelling (SME) berbasis varian atau Partial Least Square (PLS). Hasil dari penelitian ini menunjukkan bahwa quality belief memberikan pengaruh langsung dan signifikan terhadap sikap dan minat pemesanan, dan sikap konsumen yang positif memberikan dampak yang signifikan terhadap minat pemesanan hotel. Sedangkan utility dan trust belief tidak menunjukkan pengaruh signifikan terhadap pembentukan sikap dan minat konsumen dalam melakukan pemesanan hotel di Traveloka.
\end{abstract}

Kata kunci: Kepercayaan; Utility belief; Trust belief; Quality belief; Sikap; Minat Pemesanan.

\begin{abstract}
This study aims to examine the effect of belief (utility, trust, and quality) on attitudes and hotel booking intention at Traveloka. This paper employed quantitative approach by distributing questionnaires to 110 respondents who ever made any bookings on Traveloka and read online reviews about hotels on Traveloka within the last 2 years. Multivariates analysis was employed by using Structural Equation Modelling (SEM) technique based on Partial Least Square. The results of this study revealed that quality belief had a direct and significant effect on attitudes and booking intention, and positive consumer attitudes had a significant impact on hotel booking intention. In addition, utility and trust belief had no significant effect on attitudes and consumer intention on hotel booking at Traveloka.
\end{abstract}

Keywords: Beliefs; Utility belief; Trust belief; Quality belief; Attitudes; Booking Intention.

\section{PENDAHULUAN}

Pada zaman yang sudah semakin maju ini, perkembangan internet telah membuat perubahan yang besar dalam hal berkomunikasi. Hasil riset We Are Social pada tahun 2020 menyebutkan bahwa terdapat 175,4 juta $(64 \%)$ dari penduduk Indonesia telah menggunakan internet (Haryanto, 2020). Tidak hanya perubahan dalam hal berkomunikasi, perubahan juga terdapat pada cara seseorang melakukan pembelian.

Saat ini, sebagian besar orang beralih dari melakukan pembelian secara offline menjadi online. Studi menunjukkan bahwa Indonesia saat ini memiliki jumlah konsumen digital yang sudah mencapai 53\% atau setengah dari total populasi Indonesia di tahun 2018 (Putri, 2020). Dari 53\% tersebut yang berusia 15 tahun ke atas diketahui telah bertransaksi secara online.
Banyak jenis transaksi yang dapat dilakukan secara online, contohnya adalah transaksi untuk pemesanan akomodasi maupun transportasi.

Menurut survei yang dilakukan oleh Ryza (2015) sebagian besar orang memilih untuk melakukan pembelian tiket secara online atau biasa disebut e-tiket (elektronik tiket). Alasan pembelian secara online ini adalah cepat, mudah, dan nyaman. Selain tiga alasan tersebut, alasan lain seperti aman, murah, tidak perlu mengantri dan sering adanya promosi juga muncul dalam survei tersebut. Pada saat ini, pembelian e-ticket banyak dilakukan melalui platform Online Travel Agent (OTA). Banyak sekali OTA di Indonesia dan salah satunya adalah Traveloka. Berdasarkan hasil riset Alvara Research yang dilakukan pada tahun 2019 terhadap 1.204 responden, disebutkan bahwa Traveloka merupakan aplikasi OTA paling populer dan banyak digunakan di Indonesia. Hal itu ditunjukkan 
dari hasil riset bahwa 79\% responden telah menggunakan Traveloka (Triwijanarko, 2019) dan juga menurut hasil survei yang dilakukan oleh JakPat terhadap 2013 responden sebanyak $76,22 \%$ pengguna menggunakan Traveloka untuk melakukan pembelian online (Zebua, 2018).

Dahulu konsumen cenderung untuk melihat atau mendapatkan informasi mengenai akomodasi maupun transportasi secara langsung atau disebut juga dengan traditional word-of-mouth atau WOM. Akan tetapi seiring dengan kemajuan teknologi yang terus menerus berkembang dan banyaknya orang yang memakai internet, tradisional WOM telah digantikan dan berevolusi menjadi electronic word-of-mouth (E-WOM) sebagai sarana komunikasi (Reyes-Menendez, Saura, \& Martinez-Navalon, 2019). Salah satu bentuk dari EWOM adalah ulasan online.

Ulasan online dapat mempengaruhi persepsi dan pengambilan keputusan dari seorang konsumen secara signifikan ketika ingin membeli suatu produk (Chen, Ching, \& Kuo, 2018). Menurut penelitian yang dilakukan oleh Casado-Díaz, andreu, and Beckmann (2020) dan Um (2018), ulasan online dan sikap (attitude) terhadap suatu social commerce dapat berpengaruh pada minat beli atau pemesanan suatu produk atau jasa. Penelitian terdahulu juga menemukan bahwa sikap terhadap pembelian secara online mempengaruhi intensi untuk menggunakan e-commerce dan melakukan pembelian secara online di internet (Um, 2018). Oleh karena itu, ulasan online berperan penting pada keputusan membeli dan sikap dari seorang konsumen.

Ulasan online dapat dijangkau oleh setiap konsumen. Menurut Sparks, Perkins, dan Buckley (2013) ulasan online yang dinilai kurang jelas seperti kurang jelas dalam hal penulis yang menulis ulasan tersebut serta kurang spesifik dan kesesuaian dari isi ulasan tersebut dapat mempengaruhi konsumen. Oleh karena itu, menurut Sparks et al (2013) dan Um (2018) setiap ulasan harus memiliki faktor yang dapat mendukung agar ulasan tersebut dapat mempengaruhi sikap dan minat beli konsumen. Menurut Filieri (2015) dan Filieri et al (2018) kejelasan suatu ulasan yang dibuat oleh sumber dapat mempengaruhi kegunaan dari suatu ulasan, oleh karena itu ulasan yang faktual, spesifik, kredibel dan terpercaya dapat menjadi informasi yang berguna karena ulasan tersebut memberi informasi yang dapat mempengaruhi sikap dan minat beli konsumen. Sebagian besar penelitian sebelumnya hanya membahas ulasan online dari dimensi Usefulness of online review, Reviewer Expertise, Timeliness of online review, Volume of online review, Valence of online review, Comprehensiveness of online review (Santoso, 2020). Namun, belum banyak yang melihat dari sisi kepercayaan. Menurut Sparks et al (2013), kepercayaan (beliefs) juga dapat mempengaruhi minat beli konsumen yang dimediasi oleh sikap. Sikap yang dimaksud adalah kumpulan kepercayaan dari tiap individu yang didapat dari suatu objek tertentu, dalam hal ini adalah ulasan online. Oleh karena itu, sikap konsumen terhadap suatu hal tidak hanya memprediksi keinginan konsumen untuk melakukan pembelian, tetapi juga untuk menjadi suatu media yang mempengaruhi sebuah kepercayaan yang dibentuk dari informasi online yang dapat membentuk sebuah minat beli (Sparks et al, 2013).

Penelitian mengenai ulasan online telah banyak dilakukan, namun sebagian besar terfokus pada dimensi dari ulasan online pada OTA Tripadvisor yang merupakan situs Internasional yang terletak di luar negri. Tidak banyak ditemukan penelitian yang menggali mengenai kepercayaan seseorang dalam melakukan pembelian secara online yang mempengaruhi sikap dan minat beli, khususnya pada OTA Traveloka. Oleh karena itu, peneliti tertarik untuk menginvestigasi lebih dalam mengenai kepercayaan konsumen yang diadopsi dari Sparks et al (2013) yaitu utility belief, trust belief, dan quality belief serta pengaruhnya terhadap sikap dan minat beli konsumen pada Traveloka. Penelitian ini diharapkan dapat membantu OTA Traveloka dalam mengetahui dan menggali lebih dalam sikap dari konsumen agar dapat membentuk kepercayaan konsumen terhadap OTA Traveloka serta meningkatkan minat beli konsumen.

\section{TINJAUAN PUSTAKA}

\section{Kepercayaan (Beliefs)}

Kepercayaan adalah kemauan seseorang untuk bertumpu pada seseorang yang lain dimana seseorang tersebut memiliki keyakinan seseorang yang lain (Armayanti, 2012). Menurut Sparks et al., (2013) kepercayaan dapat mempengaruhi persepsi tentang sumber dari ulasan mengenai niat suatu sumber untuk mempengaruhi keputusan konsumen. Kepercayaan merupakan salah satu aspek psikologis yang dapat mempengaruhi suatu keputusan (Simamora, 2009). Menurut Mowen dan Minor (2002) kepercayaan konsumen yaitu semua pengetahuan yang dimiliki dan semua kesimpulan yang dibuat oleh konsumen tentang suatu objek, atribut serta manfaatnya. Kepercayaan konsumen merupaka kesediaan suatu pihak menerima resiko dari pihak lain menurut keyakinan dan harapan jika pihak lain tersebut akan melakukan tindakan sesuai harapan suatu pihak tersebut, walaupun kedua belah pihak belum saling mengenal (Armayanti, 2012). 


\section{Kepercayaan terhadap Ulasan Online}

Dalam hal melakukan pembelian online, kepercayaan merupakan suatu hal yang penting. Beberapa marketplace menyediakan sebuah platform untuk konsumen melihat ulasan-ulasan mengenai produk atau jasa tersebut (Tussafinah, 2018). Tussafinah (2018) mengatakan bahwa ulasan online dapat meningkatkan kepercayaan konsumen. Sebuah pesan dibuat atau didesain untuk mempengaruhi kepercayaan (Sparks et al, 2013). Calon konsumen saat memeriksa sebuah informasi dari sebuah situs ulasan online, calon konsumen cenderung membentuk kesan mengenai konteks ulasan tersebut. Teori persuasi juga mengatakan bahwa kepercayaan dapat dipengaruhi oleh persepsi mengenai sebuah pesan. Maka dari itu, kepercayaan terhadap sebuah ulasan online merupakan hal yang sangat penting.

Menurut Sparks et al (2013), Kepercayaan dapat dibagi menjadi empat aspek yaitu utility belief, trust belief, quality beliefdan CSR belief. Akan tetapi, dalam penelitian ini, peneliti hanya menggunakan 3 kepercayaan dari 4 kepercayaan yang dituliskan oleh Sparks et al (2013) yaitu utility belief, trust belief, dan quality belief. CSR belief tidak digunakan dalam penelitian ini karena Sparks et al (2013) melakukan penelitian mengenai Eco Resort, dimana Eco Resort memiliki hubungan erat dengan CSR seperti hubungan resort dengan lingkungan sekitarnya, sedangkan pada penelitian ini peneliti mengulas tentang Online Travel Agent Traveloka yang merupakan produk digital sehingga CSR belief dirasakan tidak relevan untuk penelitian ini. Utility belief, merupakan kegunaan suatu ulasan online (Sparks et al, 2013). Calon konsumen cenderung untuk membentuk kesan tentang isi dari ulasan tersebut termasuk kepercayaan mengenai kegunaan ulasan tersebut. Orang yang merasakan tingginya kegunaan sebuah informasi akan memiliki kecenderungan untuk penggunaan informasi tersebut. Hal ini secara langsung akan berpengaruh positif terhadap penggunaan informasi (Anggraini, 2008). Trust belief, merupakan ekspektasi konsumen bahwa produsen produk atau penyedia jasa tidak akan berperilaku secara oportunistik atau menguntungkan kepentingan pribadi dan tidak akan memanfaatkan situasi ketergantungan dan kerentanan yang mungkin dialami konsumen (Forgas-Coll, Palau-Saumell, Sánchez-García, \& Garrigos-Simon, 2016). Trust belief adalah persepsi seseorang terhadap karakteristik orang ataupun hal lain, yang dapat mencakup kompetensi, kemampuan untuk melakukan hal yang diinginkan, integritas diri, kejujuran, dan dapat menepati janji (Gill et al., 2005). Quality belief, merupakan kualitas yang ada dalam suatu ulasan online dimana kualitas argumen ditulis dalam ulasan online tersebut dapat dipercaya dan dapat mempersuasi pembeli atau tidak (Cheung et al, 2008).

\section{Sikap (Attitude)}

Sikap adalah sejauh mana seseorang memiliki niat terhadap produk tertentu. Semakin menguntungkan sikap, semakin besar niat individu untuk melakukan perilaku tertentu (Garg \& Joshi, 2018). Menurut Maio, Haddock, dan Verplanken (2019), sikap adalah hasil evaluasi keseluruhan dari suatu hal yang didasarkan pada informasi kognitif, afektif, dan perilaku. Telah dijelaskan di dalam suatu expectancyvalue model bahwa sikap terhadap perilaku tertentu diidentifikasi dari kumpulan sikap tentang kepercayaan. Maka dari itu, sikap adalah bagian penting dari perilaku seorang manusia (Garg \& Joshi, 2018). Sikap mempengaruhi perilaku konsumen seperti dalam hal melakukan pembelian (Um, 2018). Menurut Churiyah (2007) sikap adalah suatu respon individu terhadap suatu objek sikap yang dapat dilihat dari tiga komponen, yaitu: (1) kognitif, merupakan sikap yang menggambarkan sebuah pengetahuan dan persepsi terhadap suatu objek sikap. Pengetahuan dan persepsi dapat berbentuk kepercayaan (beliefs) yang berarti konsumen mempercayai bahwa sebuah objek sikap memiliki atribut, perilaku, dan arah hasil yang spesifik; (2) afektif, merupakan perasaan dan emosi seseorang yang merupakan evaluasi menyeluruh terhadap suatu produk tertentu; (3) konatif, merupakan kecenderungan seseorang untuk melakukan kehendak atau tindakan tertentu yang berkaitan dengan objek sikap. Objek sikap yang dimaksud adalah produk atau merek.

\section{Minat Pemesanan}

Minat adalah keinginan dalam diri seorang individu pada objek atau hal tertentu (Fatimah, 2019). Menurut Anggraini (2008), pemesanan atau reservasi adalah suatu transaksi mengenai penyediaan suatu tempat, pelayanan khusus serta fasilitas-fasilitas lainnya untuk konsumen seperti pemesanan tiket, akomodasi, dan lainnya. Sedangkan minat pemesanan adalah kegiatan dari seorang individu yang melakukan pemesanan terhadap suatu produk atau jasa (Santoso, 2020). Menurut Lin, Wen, Huang dan Wu (2015), dalam konteks melakukan pemesanan, minat beli konsumen dapat diartikan menjadi keinginan konsumen untuk melakukan pemesanan atau reservasi suatu kamar hotel. Menurut Ferdinand (2002), minat beli dapat dibedakan menjadi 4 yaitu: (1) minat transaksional yaitu kecenderungan seseorang untuk membeli suatu produk atau jasa; (2) minat referensial yaitu kecenderungan seseorang untuk menyarankan suatu produk atau jasa kepada orang lain; (3) Minat 
Preferensial yaitu minat yang menggambarkan perilaku seseorang yang memiliki preferensi utama pada produk atau jasa tersebut; dan (4) Minat Eksploratif, menggambarkan perilaku seseorang yang selalu mencari informasi pada suatu halaman ulasan ataupun lainnya mengenai produk atau jasa yang diminatinya serta mencari informasi untuk mendukung hal-hal positif dari produk atau jasa tersebut

\section{Hubungan Antara Kepercayaan dan Sikap}

Kepercayaan dan sikap adalah dua hal yang saling berhubungan. Pollay and Mittal (1993) berargumentasi bahwa kepercayaan adalah pernyataan yang spesifik dari suatu objek, sedangkan sikap adalah ringkasan atau rangkuman tentang evaluasi suatu objek. Kepercayaan konsumen dan sikap konsumen adalah indikator yang sangat penting dalam keefektifitasan suatu kegiatan (Mehta, 2000). Menurut Wang dan Sun (2010), kepercayaan seseorang dengan sikap sudah saling berhubungan sejak dahulu terhadap suatu kegiatan. Sikap konsumen terhadap suatu kegiatan dibentuk dari kepercayaan. Menurut Sparks et al (2013), utility belief dapat mempengaruhi sikap konsumen untuk menginap di sebuah hotel. Utility belief juga mempengaruhi minat pemesanan atau minat pembelian konsumen. Menurut Forgas-coll et al (2016), terdapat hubungan yang erat antara trust belief dan sikap. Trust belief juga dapat mempengaruhi sikap konsumen untuk menginap di sebuah hotel serta dapat mempengaruhi minat pemesanan atau minat pembelian konsumen (Sparks et al, 2013). Quality belief memiliki pengaruh terhadap sikap konsumen untuk menginap di sebuah hotel (Cheung et al, 2008). Cheung et al (2008) juga mengatakan bahwa quality belief juga mempengaruhi minat pemesanan atau minat pembelian konsumen.

H1: Utility belief berpengaruh signifikan terhadap sikap konsumen dalam melakukan pemesanan hotel

H2: Trust belief berpengaruh signifikan terhadap sikap konsumen dalam melakukan pemesanan hotel

H3: Quality berpengaruh signifikan terhadap sikap konsumen dalam melakukan pemesanan hotel

\section{Hubungan Antara Kepercayaan dan Minat Pemesanan}

Sikap sebagai variabel mediasi dapat diartikan sebagai kumpulan kepercayaan dari tiap individu yang didapat dari suatu objek tertentu. Oleh karena itu, sikap konsumen terhadap suatu hal tidak hanya memprediksi keinginan konsumen untuk melakukan pembelian atau pemesanan, tetapi juga untuk menjadi suatu media yang mempengaruhi sebuah kepercayaan yang dibentuk dari informasi online yang dapat membentuk sebuah minat beli atau pemesanan (Sparks et al, 2013).

H4: Utility belief berpengaruh signifikan terhadap minat pemesanan hotel

H5: Trust belief berpengaruh signifikan terhadap minat pemesanan hotel

H6: Quality belief berpengaruh signifikan terhadap minat pemesanan hotel

\section{Hubungan Antara Sikap dan Minat Pemesanan}

Sikap dan minat pemesanan menunjukkan bahwa keduanya memiliki hubungan paralel dalam consumer studies. Chen (2007) mengatakan bahwa sikap yang berkenan dan memuaskan terhadap suatu produk merupakan indikator yang dapat mempengaruhi minat pemesanan konsumen. Sikap dikatakan memiliki pengaruh yang sangat besar dalam minat pemesanan (Lim et al., 2017). Menurut penelitian yang dilakukan oleh Sparks et al (2013), sikap dan kepercayaan terhadap ulasan online memiliki hubungan yang kuat dengan minat pemesanan.

H7: Sikap berpengaruh signifikan terhadap minat pemesanan hotel

\section{METODE PENELITIAN}

Penelitian ini menggunakan pendekatan kuantitatif kausal dengan menggunakan metode survei melalui kuesioner sebagai sarana untuk mengumpulkan data. Pengambilan sampel dilakukan dengan menggunakan purposive sampling dimana kriteria yang ditentukan adalah responden yang memiliki usia minimal 17 tahun dan pernah melakukan pemesanan apapun pada Traveloka (misal: hotel, pesawat, atraksi, dan lainnya) dan membaca ulasan (online review) mengenai hotel di Traveloka dalam 2 tahun terakhir (Oktober 2018 - September 2020). Dalam penelitian ini, penulis membagikan kuesioner secara online dengan menggunakan google form. Dari 131 kuesioner yang diperoleh, terdapat 21 kuesioner yang tidak memenuhi kriteria, sehingga hanya 110 kuesioner yang dapat diolah untuk pengujian lebih lanjut. Skala yang digunakan pada penelitian ini adalah skala Likert yang mempunyai level pengukuran dari 1 (sangat tidak setuju) sampai dengan 5 (sangat setuju).

Untuk menguji hipotesis dalam penelitian ini, peneliti menggunakan Analisa multivariat dengan menggunakan teknik Structural Equation Modelling (SME) berbasis varian atau Partial Least Square (PLS) serta menggunakan software SmartPLS. Adapun model penelitian dapat dilihat pada gambar 1 dibawah ini. 


\section{HASIL PENELITIAN DAN PEMBAHASAN}

\section{Profil Responden}

Mayoritas responden adalah perempuan sebanyak 82 orang $(74,5 \%)$ sedangkan responden lakilaki sebanyak 28 orang $(25,5 \%)$. Berdasarkan usia, sebagian besar responden berusia 17-23 tahun sebanyak 71 orang $(64,5 \%)$ dan berstatus sebagai mahasiswa/pelajar sebanyak 67 orang $(60,9 \%)$ dengan pendidikan terakhir SMA/SMK sebanyak 65 orang $(59,1 \%)$ dan memiliki uang saku/pendapatan kurang dari Rp 3.000.000 sebanyak 41 orang dengan persentase $37.3 \%$. Frekuensi responden dalam melakukan pemesanan hotel di Traveloka dalam dua tahun terakhir sebanyak 1-3 kali $(50,9 \%)$ dan melakukan perjalanan sebanyak 1-5 kali (55,5\%). Hampir semua responden $(94,5 \%)$ memiliki akun traveloka sendiri. Selain melalui Traveloka, responden paling banyak memilih untuk melakukan pemesanan hotel melalui tiket.com $(53,6 \%)$.

\section{Analisa Statistik Deskriptif}

Dari Tabel 2 dapat dilihat bahwa dalam variabel kepercayaan dengan dimensi utility memiliki nilai mean tertinggi $(4,30)$ diikuti dengan trust dan quality dengan mean yang sama $(3,97)$. Hasil ini menyatakan bahwa responden cenderung untuk percaya bahwa ulasan online di Traveloka dirasakan bermanfaat, informatif, dan akurat. Untuk variabel sikap, sikap kognitif memiliki nilai mean tertinggi $(4,11)$, diikuti oleh afektif $(3,90)$ dan konatif $(3,88)$. Hal ini menunjukkan bahwa ketika memilih menginap di sebuah hotel, responden memiliki pengetahuan dan persepsi yang baik mengenai hotel tersebut. Melalui ulasan yang diberikan di Traveloka membantu responden untuk membentuk persepsi yang positif mengenai

Tabel 1. Hasil Mean dan Standar Deviasi

\begin{tabular}{|c|c|c|}
\hline Pernyataan & Mean & Standar Deviasi \\
\hline Utility Belief & 4,30 & $\mathbf{0 , 7 3}$ \\
\hline X1.1 Percaya bahwa ulasan online tersebut bermanfaat & 4,51 & 0,68 \\
\hline X1.2 Percaya bahwa ulasanonline tersebut informatif & 4,46 & 0,64 \\
\hline X1.3 Percaya bahwa ulasan online tersebut akurat & 3,93 & 0,85 \\
\hline Trust Belief & 3.97 & 0.85 \\
\hline X2.1 Percaya bahwa ulasan online tersebut dapat diandalkan & 3,97 & 0,81 \\
\hline X2.2 Percaya bahwa ulasan online tersebut dapat memenuhi harapan & 3,94 & 0,85 \\
\hline X2.3 Percaya bahwa ulasan online tersebut dapat dipercaya & 4,06 & 0,78 \\
\hline X2.4 Percaya bahwa ulasan online tersebut ditulis apa adanya & 4,07 & 0,94 \\
\hline X2.5 Percaya bahwa ulasan online tersebut ditulis oleh orang yang berpengetahuan baik & 3,66 & 0,86 \\
\hline $\begin{array}{l}\text { X2.6 Percaya bahwa ulasan online tersebut ditulis oleh orang yang memiliki pengalaman yang } \\
\text { baik }\end{array}$ & 3,84 & 0,87 \\
\hline X2.7 Percaya bahwa ulasan online tersebut mementingkan kepentingan konsumen & 4,25 & 0,86 \\
\hline Quality Belief & 3.97 & 0.87 \\
\hline X3.1 Percaya bahwa ulasan online tersebut relevan & 4,16 & 0,77 \\
\hline X3.2 Percaya bahwa ulasan online tersebut selalu baru (up-to-date) & 4,01 & 0,89 \\
\hline X3.3 Percaya bahwa ulasan online tersebut sesuai dengan fakta yang ada (aktual) & 4,06 & 0,86 \\
\hline X3.4 Percaya bahwa ulasan online tersebut komprehensif atau lengkap & 3,65 & 0,98 \\
\hline Sikap Kognitif & 4.11 & 0.74 \\
\hline Z1.1 Memiliki pengetahuan yang baik untuk menginap di hotel yang telah diulas pada Traveloka & 4,01 & 0,78 \\
\hline Z1.2 Memiliki persepsi yang baik untuk menginap di hotel yang telah diulas pada Traveloka & 4,20 & 0,70 \\
\hline Sikap Afektif & 3.90 & 0.79 \\
\hline Z2.1 Merasa bahwa menginap di hotel yang diulas pada Traveloka akan menarik & 3,99 & 0,84 \\
\hline Z2.2 Merasa ingin menginap di hotel yang diulas pada Traveloka & 3,88 & 0,75 \\
\hline Z2.3 Merasa bahwa menginap di hotel yang diulas pada Traveloka menyenangkan & 3,83 & 0,77 \\
\hline Sikap Konatif & 3.88 & 0.91 \\
\hline Z3.1 Cenderung memiliki keinginan untuk menginap di hotel yang diulas pada Traveloka & 3,85 & 0,91 \\
\hline Z3.2 Cenderung memiliki ketertarikan untuk menginap di hotel yang diulas pada Traveloka & 3,91 & 0,92 \\
\hline Minat Pemesanan & 4.06 & 0.93 \\
\hline Y1 Cenderung akan melakukan pemesanan hotel pada Traveloka & 4,06 & 0,85 \\
\hline $\begin{array}{l}\text { Cenderung akan melakukan pemesanan hotel pada Traveloka setelah mendapatkan saran } \\
\text { atau rekomendasi dari orang lain }\end{array}$ & 3,96 & 0,88 \\
\hline Menjadikan Traveloka preferensi utama saya untuk melakukan pemesanan hotel & ,91 & 1,00 \\
\hline $\begin{array}{l}\text { Y4 Selalu mencari informasi dari halaman ulasan yang disediakan Traveloka sebelum } \\
\text { melakukan pemesanan hotel }\end{array}$ & 4,28 & 0,99 \\
\hline
\end{tabular}


hotel tersebut. Sedangkan untuk minat pemesanan, minat eksploratif memiliki mean tertinggi $(4,28)$ diikuti dengan minat transaksional $(4,06)$ dan minat referensial $(3,96)$. Hal ini menyatakan bahwa responden cenderung untuk selalu mencari informasi dari halaman ulasan yang disediakan Traveloka sebelum melakukan pemesanan hotel. Hasil dari mean dan standar deviasi dari kepercayaan, sikap, dan minat pemesanan dapat dilihat pada Tabel 1 .

\section{Measurement Model}

Berdasarkan Tabel 2 dapat dilihat bahwa semua nilai AVE dari utility belief, trust belief, quality belief, sikap dan minat pemesanan berkisar antara 0,50-0,70 yang berarti telah memenuhi syarat dari convergent validity yang harus berkisar antara 0.5 atau lebih dari 0,5 . Sedangkan composite reliability harus lebih besar dari 0,7 dan semua variabel menunjukkan nilai diatas 0,80 yang berarti dapat dikatakan reliabel. Hasil validitas diskriminan dari setiap indikator terhadap variabelnya lebih tinggi dibandingkan dengan nilai korelasi terhadap variabel lainnya, maka indikator dalam uji discriminant validity terbukti valid. Lebih lanjut, hasil uji Cronbach's Alpha dari variabel kepercayaan yang dilihat dari utility belief, trust belief, dan quality belief, sikap, dan minat pemesanan menunjukkan nilai diatas 0.6 sehingga dapat dikatakan reliabel.

Tabel 2. AVE, Composite Reliability, Cronbach's Alpha

\begin{tabular}{lccc}
\hline \multicolumn{1}{c}{ Variabel } & AVE & $\begin{array}{c}\text { Composite } \\
\text { Reliability }\end{array}$ & $\begin{array}{c}\text { Cronbach's } \\
\text { Alpha }\end{array}$ \\
\hline Utility belief & 0.70 & 0.85 & 0.74 \\
Trust belief & 0.50 & 0.87 & 0.83 \\
Quality belief & 0.63 & 0.87 & 0.81 \\
Sikap & 0.54 & 0.89 & 0.86 \\
Minat pemesanan & 0.52 & 0.81 & 0.69 \\
\hline
\end{tabular}

\section{Structural Model}

Nilai $R$-square dari variabel sikap adalah sebesar 0.282 yang berarti bahwa sikap dapat dijelaskan sebesar $28.2 \%$ oleh variabel kepercayaan yang dilihat dari utility belief, trust belief, dan quality belief dengan pengkategorian lemah. Nilai $R$-square dari variabel minat pemesanan adalah sebesar 0.399 yang berarti bahwa minat pemesanan dapat dijelaskan sebesar $39.9 \%$ oleh variabel kepercayaan yang dilihat dari utility belief, trust belief, dan quality belief dengan pengkategorian moderat.

Pengujian kesesuaian model dilakukan dengan cara melakukan uji stone geisser atau $Q$-square yang dilakukan untuk mengukur seberapa baik nilai observasi yang dihasilkan oleh model yang digunakan dalam penelitian. Nilai $Q$-square yang didapatkan adalah sebesar 0,568 yang menunjukkan bahwa model penelitian ini memiliki predictive relevance dan layak untuk digunakan. Hasil 0,568 menunjukkan nilai $Q$ square adalah besar dan nilai observasi yang dihasilkan oleh model dan juga estimasi parameternya memiliki ketepatan sebesar 56,8\%. Berdasarkan hasil ini, model struktural yang digunakan dalam penelitian ini maka memiliki nilai goodness of fit yang baik.

Tabel 3 dibawah ini menunjukkan hubungan kausal antara kepercayaan (yang dilihat dari utility belief, trust belief, dan quality belief), sikap dan minat pemesanan.

Tabel 3. Analisa Path Coefficients

\begin{tabular}{lccc}
\hline \multicolumn{1}{c}{ Hipotesis } & $\begin{array}{c}\text { Path } \\
\text { Coefficient }\end{array}$ & T-value & Hasil hipotesis \\
\hline H1: Utility belief $\rightarrow$ Sikap & 0.152 & 1.270 & Tidak diterima \\
H2: Trust belief $\rightarrow$ Sikap & 0.178 & 1.288 & Tidak diterima \\
H3: Quality belief $\rightarrow$ Sikap & 0.380 & $2.955^{* *}$ & Diterima \\
$\begin{array}{c}\text { H4: Utility belief } \rightarrow \text { Minat } \\
\text { pemesanan }\end{array}$ & 0.081 & 1.192 & Tidak diterima \\
$\begin{array}{c}\text { H5: Trust belief } \rightarrow \text { Minat } \\
\text { pemesanan }\end{array}$ & 0.095 & 1.286 & Tidak diterima \\
$\begin{array}{c}\text { H6: Quality belief } \rightarrow \text { Minat } \\
\text { pemesanan }\end{array}$ & 0.202 & $2.549 *$ & Diterima \\
$\begin{array}{c}\text { H7: Sikap } \rightarrow \text { Minat } \\
\text { Pemesanan }\end{array}$ & 0.531 & $7.833 * *$ & Diterima \\
\hline
\end{tabular}

${ }^{* *}$ Tingkat signifikansi 0,01

${ }^{*}$ Tingkat signifikansi 0,05

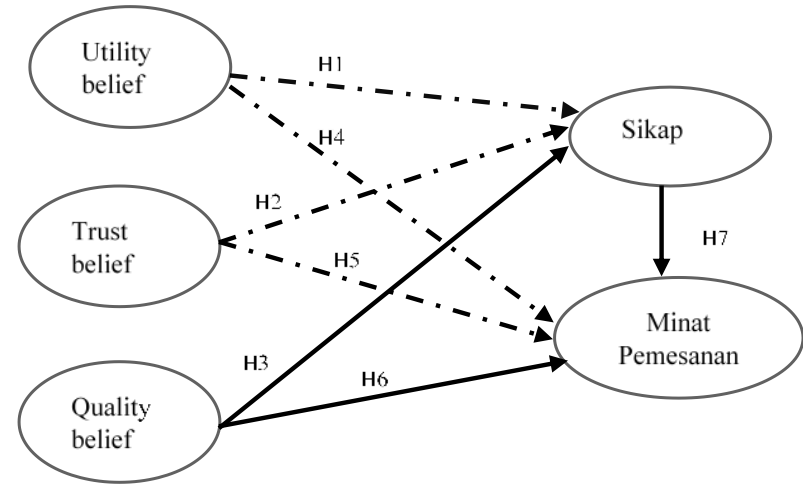

Gambar 1. Direct path of the structural model

\section{Pengaruh Kepercayaan terhadap Sikap}

Dari Tabel 3 dan Gambar 1 dapat dilihat bahwa utility belief dan trust belief hanya memberikan pengaruh positif namun tidak signifikan terhadap sikap konsumen dalam melakukan pemesanan hotel di Traveloka sehingga $\mathrm{H} 1$ dan $\mathrm{H} 2$ dalam penelitian ini ditolak. Konsumen percaya bahwa ulasan online tersebut bermanfaat, informatif dan akurat tetapi tidak terbukti dapat membentuk sikap konsumen untuk melakukan pemesanan hotel. Hal tersebut dapat terjadi 
karena maraknya manipulasi pada ulasan online seperti ulasan online yang secara sengaja dibuat positif (sedikit yang negatif) oleh oknum tertentu sehingga membuat kurangnya kepercayaan konsumen terhadap ulasan online yang ada. Dapat dilihat dari laporan organisasi penelitian Mintel yang mengatakan bahwa terdapat sekitar 57 persen dari konsumen yang disurvei mencurigai jika suatu perusahaan atau produk hanya memiliki ulasan positif dan tidak memiliki ulasan negatif. Selain itu, sekitar 49 persen konsumen juga percaya suatu perusahaan mungkin memberi insentif atau bonus kepada konsumen yang memberi ulasan online. Terjadinya kasus jual beli ulasan online (CNN Indonesia, 2018) yang dapat membuat keyakinan konsumen untuk percaya pada suatu ulasan online berkurang. Oleh karena itu konsumen mengatakan bahwa kepercayaan dari sebuah ulasan tidak mempengaruhi keyakinan seorang konsumen serta tidak mempengaruhi sikap konsumen itu sendiri. Hasil penelitian ini tidak selaras dengan penelitian terdahulu yang dilakukan oleh Sparks et al (2013) dan Forgascoll et al (2016) yang mengatakan bahwa utility belief dan trust belief berpengaruh pada sikap konsumen. Hal ini bisa saja disebabkan adanya perbedaan industri dalam pengujian ini dengan penelitian terdahulu yang mengambil industri eco resort sedangkan penelitian ini pada industri online travel agent.

Kepercayaan yang dilihat dari dimensi Quality berpengaruh signifikan terhadap sikap konsumen dalam melakukan pemesanan hotel. Berdasarkan hasil penelitian ini, $\mathrm{H} 3$ dinyatakan diterima karena quality belief memberikan pengaruh positif dan signifikan terhadap sikap konsumen dalam melakukan pemesanan hotel di Traveloka. Pada masa sekarang, konsumen dapat dengan cepat dan mudah untuk mendapatkan informasi. Informasi dapat dengan mudah didapatkan melalui berbagai media salah satunya internet. Oleh karena adanya kemudahan dalam mencari informasi, konsumen kini lebih percaya dengan informasi terbaru (up-to-date). Informasi yang relevan, aktual, dan lengkap dianggap lebih dapat dipercaya oleh konsumen.

\section{Pengaruh Kepercayaan terhadap Minat Pemesanan}

Hasil dari penelitian ini menunjukkan bahwa, hanya kepercayaan mengenai kualitas (quality belief) dari ulasan online yang memberikan pengaruh langsung dan signifikan terhadap minat pemesanan, yang berarti $\mathrm{H} 6$ diterima. Sedangkan utility belief dan trust belief tidak memberikan pengaruh siginifikan terhadap minat pemesanan yang berarti $\mathrm{H} 4$ dan $\mathrm{H} 5$ ditolak. Persepsi, pengetahuan, kecenderungan, emosi dan perasaan yang merupakan bagian dari sikap dipengaruhi oleh kepercayaan konsumen atas kualitas dari ulasan online terhadap minat pemesanan, sehingga pada saat konsumen membaca ulasan online dan percaya dengan kualitas ulasan tersebut, konsumen memiliki sikap untuk menginap di hotel. Jika seorang konsumen telah memiliki sikap untuk menginap, maka konsumen akan melakukan pemesanan pada hotel yang diulas di Traveloka dimana jika konsumen akan menginap, konsumen tersebut harus memesan kamar hotel. Konsumen menganggap bahwa kepercayaan mengenai kualitas dari ulasan online itu lebih penting dan lebih berpengaruh pada sikap konsumen untuk menginap di hotel yang diulas pada Traveloka, dari sikap tersebut konsumen melakukan atau memiliki minat pemesanan pada hotel yang ada di Traveloka..

\section{Pengaruh Sikap terhadap Minat Pemesanan}

T-value dari hubungan sikap dan minat pemesanan mempunyai korelasi paling tinggi dengan nilai koefisien 0.531 dan signifikan dengan level signifikansi 0,01 , sehingga $\mathrm{H} 7$ dalam penelitian ini dapat diterima. Hal ini mengidentifikasikan bahwa sikap positif konsumen terhadap ulasan online di Traveloka akan berimbas pada meningkatnya minat konsumen untuk melakukan pemesanan. Konsumen memiliki pengetahuan yang baik dan persepsi yang baik setelah melihat ulasan mengenai hotel pada Traveloka. Konsumen juga merasa ingin menginap, tertarik, dan merasa bahwa menginap di hotel yang diulas pada Traveloka menyenangkan. Konsumen juga cenderung memiliki ketertarikan dan keinginan untuk menginap di hotel tersebut. Sikap dari konsumen ini mempengaruhi minat pemesanan hotel itu sendiri karena jika konsumen memiliki sikap ingin, tertarik, dan cenderung ingin untuk menginap pada hotel yang diulas pada Traveloka, konsumen akan melakukan pemesanan. Kegiatan melakukan pemesanan disini memiliki arti bahwa konsumen memiliki minat pemesanan setelah memiliki sikap-sikap tersebut.

\section{SIMPULAN DAN SARAN}

Berdasarkan hasil dan pembahasan diatas, dapat disimpulkan bahwa dari tiga indikator kepercayaan (utility, trust, dan quality), hanya quality belief yang memiliki pengaruh langsung dan signifikan terhadap sikap dan minat pemesanan hotel. Kepercayaan konsumen akan kualitas ulasan online yang relevan, up-to-date, actual dan komprehensif membentuk sikap dari konsumen yang pada akhirnya mendorong minat konsumen untuk melakukan pemesanan hotel di 
Traveloka. Selain itu, penelitian ini juga menunjukkan bahwa minat melakukan pemesanan ini dapat dibentuk langsung oleh kualitas dari ulasan online tanpa melalui terbentuknya sikap dari konsumen. Lebih lanjut, sikap konsumen secara kognitif, afektif dan konatif memberikan dampak yang positif dan signifikan terhadap minat pemesanan. Sikap yang terbentuk karena merasa puas dengan suatu produk atau jasa merupakan indikator penting yang dapat meningkatkan minat pemesanan dari konsumen (Chen, 2007; Lim et al., 2017). Oleh karena itu, penting sekali bagi Traveloka untuk dapat meningkatkan kualitas dari ulasannya supaya lebih relevan, aktual dan lengkap untuk dapat membentuk sikap yang positif dari konsumen yang pada akhirnya dapat meningkatkan minat konsumen untuk melakukan pemesanan.

Penelitian ini mempunyai sampel yang terbatas pada pengguna OTA Traveloka saja, oleh karena itu diharapkan peneliti selanjutnya dapat menggunakan OTA lain seperti booking.com, tiket.com, pegi-pegi untuk dapat mengkonfirmasi hasil dari penelitian. Hasil dari penelitian ini diharapkan dapat memberikan masukan bagi OTA untuk dapat meningkatkan kualitas ulasannya sehingga dapat diterima dan membentuk sikap positif dari konsumen untuk melakukan keputusan pembelian.

\section{DAFTAR REFERENSI}

Anggraini, T. (2008). Pelayanan reservasi sistem online tiket pesawat domestik lion air di PT. Electra Duta Wisata. Unpublished undergraduate thesis, Universitas Sebelas Maret, Surakarta. 2328.

Armayanti, N. (2012). Gambaran kepercayaan konsumen terhadap pembelian melalui media internet. Unpublished undergraduate thesis, Universitas Sumatera Utara, Medan. 13-27.

Casado-Díaz, A.B, Andreu, L, Beckmann, S.C. (2020). Negative online reviews and webcare strategies in social media: effects on hotel attitude and booking intentions. Current Issues in Tourism, 23(4), 418-422.

Chen, M. F. (2007). Consumer attitudes and purchase intentions in relation to organic foods in Taiwan: moderating effects of food-related personality traits. Food Quality and Preference. 7(18), 10081021.

Chen, M. Y., Ching, I. T., \& Kuo, W. C. (2018). The helpfulness of online reviews. Online Information Review, 44(1), 90-113.

Cheung, C. M., Lee, M. K., \& Rabjohn, N. (2008). The impact of electronic word of mouth: the adoption of online opinions in online customer communities. Impact of electronic word-of-mouth. Internet Research, 18(3), 229-247.

Churiyah, E. S. (2007). Pengaruh sikap konsumen terhadap keputusan pembelian minuman merek aqua berkaitan dengan penerapan program CSR (Corporate Social Responsibility). Jurnal Ekonomi Modernisasi. 3(2), 147-162.

1. CNN Indonesia. (Dec, 2018). Konsumen adukan dugaan curang Lazada, Traveloka dan Tokopedia. Retrieved from https://www.cnnindonesia. com/ekonomi/20181217152932-92-354302/konsumen-adukan-dugaan-curang-lazada-travelokadan-tokopedia

Fatimah, N. (2019). Pengertian minat, ciri, dan contohnya. Retrieved from https://pelayananpublik.id/ 2019/08/26/pengertian-minat-ciri-dan-contohnya/

Ferdinand, A. (2002). Pengembangan minat beli merek ekstensi. Semarang: Badan Penerbit Universitas Diponegoro.

Filieri, R. (2015). What makes an online consumer review trustworthy? Annals of Tourism Research, 58, 46-64.

Filieri, R., Hofacker, C., \& Salma, A. (2018). What makes information in online consumer reviews diagnostic over time? The role of review relevancy, factuality, currency, source credibility and ranking score. Computers in Human Behavior, 80, 122-131.

Forgas-coll, S., Palau-saumell, R., Sánchez-garcía, J., \& Garrigos-simon, F. J. (2016). Comparative analysis of american and spanish cruise passengers' behavioral intentions. Revista de Administração de Empresas, 56(1), 87- 100.

Garg, P., \& Joshi, R. (2018). Purchase intention of "halal" brands in India: the mediating effect of attitude. Journal of Islamic Marketing, 9(3), 684686.

Gill, H., Boies, K., Finegan, J. E., \& McNally, J. (2005). Antecedents of trust: establishing a boundary condition for the relation between propensity to trust and intention to trust. Journal of Business and Psychology, 19(3), 287-302.

Haryanto, A. T. (2020, Februari). Riset: Ada 175, 2 juta pengguna internet di indonesia. Retrieved from https://inet.detik.com/cyberlife/d-4907674/risetada-1752-juta-pengguna-internet-di-indonesia

Lim, X. J., Radzol, A. R. M., Cheah, J. H., \& Wong, M. W. (2017). The impact of social media influencers on purchase intention and the mediation effect of customer attitude. Asian Journal of Business Research. 7(2), 20-21. 
Lin C. H., Wen M. J., Huang L.C., \& Wu K. L. (2015). Online hotel booking: the effects of brand image, price, trust and value on purchase intentions. Asia Pacific Management Review. 20, 210-218.

Maio, G., Haddock, G., \& Verplanken, B. (2019). The psychology of attitudes \& attitude change. Sage Publications

Mehta, A. (2000). Advertising attitudes and advertising effectiveness. Journal of Advertising Research, 40, 67-72.

Mowen, J., C. \& Minor, M. 2002. Perilaku konsumen. Erlangga: Jakarta.

Pollay, R., \& Mittal, B. (1993). Here's the beef: factors, determinants, and segments in consumer criticism of advertising. Journal of Marketing, 57(3), 99-114.

Putri V. M. (2020, Februari). 53\% Penduduk indonesia sudah belanja online. Detik.com. Retrieved from https://inet.detik.com/cyberlife/d-4906129/53penduduk-indonesia-sudah-belanja-online

Reyes-Menendez, A., Saura, J. R., \& MartinezNavalon, J. G. (2019). The impact of e-WOM on hotels management reputation: exploring tripadvisor review. 7, 68868-68877.

Ryza, P. (2015). Survei jakpat ungkap masyarakat sudah terbiasa membeli tiket secara online. Retrieved from https://dailysocial.id/post/surveijakpat-ungkap-masyarakat-sudah-terbiasamembeli-tiket-secara-online

Santoso, J. C. (2020). Pengaruh ulasan online terhadap minat pemesanan hotel pada pengguna Traveloka. Unpublished undergraduate thesis, Universitas Kristen Petra, Surabaya. 41-45.
Sparks, B.A., Perkins, H.E., \& Buckley, R. (2013). Online travel reviews as persuasive communication: The effects of content type, source, and certification logos on consumer behavior. Tourism Management, 39, 1-9.

Triwijanarko, R. (2019, July). Traveloka jadi aplikasi travel terpopuler di kalangan milenial. Marketeers.com. Retrieved from https://www.marketeers.com/traveloka-jadi-aplikasi-travel-terpopuler-di-kalangan-milenial/\#: :text=Menurut $\%$ \%20Alvara\%20Research\%2C\%20\%E2\%80\%8 $\mathrm{B}$,telah\%20digunakan\%20oleh\%2079\%25\%20r esponden.

Tussafinah, H. (2018). Pengaruh rating dan ulasan, jaminan 100\% pengembalian dan layanan COD atau bayar di tempat terhadap keputusan pembelian lazada. Unpublished undergraduate thesis, Universitas Islam Negeri Walisongo, Yogyakarta. 74-76.

Um, N. H. (2018). Antecedents and consequences of consumers' attitude toward social commerce sites. Journal of Promotion Management. 25(4), $1-20$.

Wang, Y., \& Sun, S. (2010). Assessing beliefs, attitudes, and behavioral responses toward online advertising in three countries. International Business Review, 19(4), 333-344.

Zebua, F. (2018, Februari). Laporan DailySocial: Survey Online Travel Agencies (OTA) 2018. Retrieved from https://dailysocial.id/post/laporan-dailysocial-survey-online-travel-agenciesota-2018/ 